\section{Palm Nutrition and Fertilization}

\author{
Timothy K. Broschat ${ }^{1}$
}

AdDitional INDEX WORDs. nitrogen, phosphorus, potassium, magnesium, iron, manganese, boron, nutrient deficiencies

SumMary. Palms (Arecaceae) growing in containers have similar nutritional requirements as other tropical ornamental plants and grow well with fertilizers having an elemental ratio of $3 \mathrm{~N}: 0.4 \mathrm{P}: 1.7 \mathrm{~K}$. However, palms growing in the landscape or field nurseries have very different nutritional requirements from dicotyledonous plants. Whereas nitrogen $(\mathrm{N})$ is the primary limiting nutrient element in container production, potassium (K), manganese (Mn), magnesium $(\mathrm{Mg})$, boron $(\mathrm{B})$, and iron $(\mathrm{Fe})$ deficiencies are more widespread than $\mathrm{N}$ deficiency in most landscape soils. Because palms have a single apical meristem, deficiencies of $\mathrm{K}, \mathrm{Mn}$, or B can be fatal. In addition to insufficient nutrients in the soil, palm nutrient deficiencies can be caused by high soil $\mathrm{pH}$, certain types of organic matter, deep planting, poor soil aeration, cold soil temperatures, and nutrient imbalances. Correction of nutritional deficiencies in palms can take up to 2 years or longer and therefore prevention of deficiencies by proper fertilization is important. Research has shown that high $\mathrm{N}: \mathrm{K}$ ratio fertilizers applied directly, or indirectly via application to adjacent turfgrass in a landscape, can exacerbate $\mathrm{K}$ and $\mathrm{Mg}$ deficiencies in palms, sometimes fatally. For sandy Atlantic coastal plain soils in the southeastern United States, an analysis of $8 \mathrm{~N}-0.9 \mathrm{P}-10 \mathrm{~K}-4 \mathrm{Mg}$ plus micronutrients has been recommended.

$\mathrm{P}$ alms are increasingly popular as landscape plants in tropical to warm temperate regions of the United States and as interiorscape plants elsewhere. While visible nutrient deficiency symptoms are relatively uncommon on dicot trees found in landscapes, palms are rarely seen without at least one nutrient deficiency. Because landscape palms are grown almost exclusively for aesthetic purposes and their leaves are very large, nutritional deficiencies are conspicuous and unattractive. Also, deficiencies that might merely cause twig dieback in dicots can be fatal in palms, which have only a single apical meristem and no lateral meristems. Thus, proper fertilization for palms is important for palm health and survival, as well as for aesthetics.

As monocots, palms have different nutritional requirements than dicot trees or shrubs. Most notable is the high potassium requirement of palms, an element that is rarely deficient in dicot trees. The purpose of this article is to review the most common nutrient deficiencies of ornamental palms and to discuss fertilization practices that address these nutritional problems in container

Ft. Lauderdale Research and Education Center, University of Florida, 3205 College Avenue, Davie, FL 33314

1Corresponding author. E-mail: tkbr@ufl.edu. production and in the field nursery or landscape.

\section{Nutritional deficiencies}

Nitrogen. Nitrogen deficiency is the most important nutritional problem in the container production of palms, yet it is relatively rare in landscape palms. Container substrates that contain pine bark and other wood-derived materials are particularly prone to $\mathrm{N}$ tie-up as these materials decompose (Ogden et al., 1987). Nitrogen, like $\mathrm{P}, \mathrm{K}$, and $\mathrm{Mg}$, is a mobile element within palms. That is, under conditions of deficiency, the palm is able to extract $\mathrm{N}$ from the oldest leaves in the canopy and translocate it to the growing new leaf (spear leaf) to allow for continued growth. For this reason, deficiency symptoms of mobile elements occur first on the oldest leaves, and as the deficiency increases in severity, progressively younger leaves will be affected. Nitrogen deficiency appears as a uniform light green to very light yellow-green color on the oldest leaves, but typically will affect the entire canopy except for the spear leaf, which may be slightly darker shade of green (Broeshart et al., 1957; Broschat, 1984; Bull, 196la; Manciot et al., 1979). When all of the mature leaves have been depleted of their mobilizable $\mathrm{N}$, the growth of the palm will slow and eventually stop altogether. Severe N deficiency does not cause tissue necrosis and thus, if properly fertilized, discolored $\mathrm{N}$ deficient older leaves are capable of re-greening.

Phosphorus. Although P deficiency has generally not been a problem in palms grown in the United States, it can be a serious limiting factor in acid tropical soils where african oil palm (Elaeis guineensis) or coconut palm (Cocos nucifera) are grown commercially (Manciot et al., 1979). Symptoms are not particularly distinctive, but appear as a uniform light olive-green coloration of the foliage. Purplish spots and/or leaflet tip necrosis may be present on the oldest leaves (Bull, 1958; Elliott et al., 2004). However, the most important symptom of $\mathrm{P}$ deficiency in all species is a sharp reduction in growth rate, with "pencil-pointing" or tapering of the trunk occurring in chronic situations (Broschat, 1984; von Uexkull and Fairhurst, 1991).

Potassium. Potassium deficiency is by far the most common deficiency of palms growing in production fields or landscapes throughout much of the world. However, in container production, it is much less common than $\mathrm{N}$ deficiency. Symptoms vary according to species and severity. In many species, the earliest symptoms consist of translucent yellow-orange and/or necrotic spots on the oldest leaves (Broschat, 1990; Bull, 196la). As the deficiency progresses, marginal and/or tip necrosis of the leaflets appears (von Uexkull and Fairhurst, 1991). In some species, spotting is never observed and leaflet tip necrosis is the only visible symptom. As with $\mathrm{N}$ deficiency, $\mathrm{K}$ is a highly mobile element within palm canopies and symptoms are most severe on the

\begin{tabular}{llll}
\hline $\begin{array}{l}\text { Units } \\
\begin{array}{l}\text { To convert U.S. to SI, } \\
\text { multiply by }\end{array}\end{array}$ & U.S. unit & SI unit & $\begin{array}{l}\text { To convert SI to U.S., } \\
\text { multiply by }\end{array}$ \\
\hline 48.8243 & $\mathrm{lb} / 1000 \mathrm{ft}^{2}$ & $\mathrm{~kg} \cdot \mathrm{ha}^{-1}$ & 0.0205 \\
1.1209 & $\mathrm{lb} / \mathrm{acre}^{-1}$ & $\mathrm{~kg} \cdot \mathrm{ha}^{-1}$ & 0.8922 \\
0.5933 & $\mathrm{lb} / \mathrm{yard}$ & $\mathrm{kg} \cdot \mathrm{m}^{-3}$ & 1.6856 \\
1 & $\mathrm{ppm}$ & $\mathrm{mg} \cdot \mathrm{L}^{-1}$ & $\mathrm{l}$
\end{tabular}


oldest leaves and toward the tips of each affected leaf. When viewed from a distance, many K-deficient palms appear to have an orange-bronze cast to the older leaves. In other cases, Kdeficient palms of the same species may show only leaflet necrosis (Broschat, 1990).

Potassium deficiency causes premature senescence of the older leaves and thus strongly affects the number of leaves that a palm can support. In a severely K-deficient palm, once all of the older leaves have died from the deficiency, the palm then goes into a rapid state of decline, with the trunk tapering (pencil-pointing), new leaves emerging chlorotic and with extensive leaflet necrosis, and finally, death of the meristem (Elliott et al., 2004). Potassium deficiency is the most common cause of mortality in royal palm (Roystonea regia) in Florida landscapes (Broschat, 2005a). Routine removal of unsightly K-deficient leaves on palms and fertilization with high $\mathrm{N}$ :K ratio fertilizers have been demonstrated to accelerate the rate of decline from K deficiency (Broschat, 1994, 2005b).

Magnesium. Magnesium deficiency also occurs on the oldest leaves, but as distinct broad lemonyellow to orange bands along the margins of the leaves. The centers of affected leaves remain dark green with an abrupt transition from yellow to green (Broschat, 1984, 2005c). In some palms with palmate leaves (fan palms), some leaves will not show a broad yellow band around the perimeter of the leaf, but rather broad yellow bands around the margins of each leaf segment, the centers of which remain distinctly green. Both patterns of $\mathrm{Mg}$ deficiency (leaf and leaf segment chlorotic banding) have been observed on different leaves on a single palm. Magnesium deficiency usually does not cause necrosis, yet necrosis caused by $\mathrm{K}$ deficiency is common on palms showing $\mathrm{Mg}$ deficiency. Canary island date palms (Phoenix canariensis) in Florida frequently display deficiencies of both elements on the same palm. Where they co-occur, classical $\mathrm{K}$ deficiency symptoms (translucent and necrotic spotting and leaflet tip necrosis) will be seen on the oldest leaves and the yellow-banded $\mathrm{Mg}$-deficient leaves will be observed above the K-deficient leaves, often in midcanopy (Broschat, 2005c). Transitional leaves will show $\mathrm{K}$ deficiency symptoms toward the leaf tips, but $\mathrm{Mg}$ deficiency symptoms will appear toward the leaf base. Chlorosis caused by $\mathrm{Mg}$ deficiency is permanent and cannot be eliminated from affected leaves by application of $\mathrm{Mg}$ fertilizers. Rather, the deficiency will be gradually eliminated from the canopy by replacement of older symptomatic leaves with newer $\mathrm{Mg}$ sufficient leaves. The process of correcting $\mathrm{K}$ and $\mathrm{Mg}$ deficiencies can take from one to three years. Magnesium deficiency in palms is accentuated by high levels of $\mathrm{N}$ and $\mathrm{K}$ in landscape soils (Broschat, 2005c; von Uexkull and Fairhurst, 1991). In container production, $\mathrm{Mg}$ deficiency is usually indicative of insufficient or exhausted dolomite in the container substrate.

IRON. Iron deficiency appears on newly emerging leaves as a uniform or interveinal chlorosis. In severe cases, new leaves may emerge almost white in color, with extensive leaf tip necrosis. Because Fe tends to accumulate in older leaves (Broschat, 1997), symptomatic leaves may green up as they mature. Leaf spot diseases such as exserohilum leaf spot (caused by Exserohilum rostratum) on foxtail palm (Wodyetia bifurcata) often are associated with Fe deficiency (Broschat and Elliott, 2005a) and cannot be controlled with fungicides unless the Fe deficiency is first corrected. The most common cause of Fe deficiency in palms is poor soil aeration, with related factors that reduce root surface area, or metabolic rate such as root rot diseases and deep planting having similar effects (Broschat and Donselman, 1985). Palms growing in calcareous soils may exhibit Fe deficiency, but not to the degree that dicot trees or shrubs are affected. Iron deficiency is common in palms grown in containers in which the substrate has decomposed, reducing root zone aeration.

Manganese. Manganese deficiency is similar to Fe deficiency in that new leaves emerge with interveinal chlorosis. However, Mn-deficient leaves differ in that they also show longitudinal necrotic streaking within the leaflets (Broschat, 2005a; Bull, 1961b). In more severe cases, the distal ends of the leaflets become completely necrotic and curled, giving the leaf a frizzled appearance. Because Mn deficiency occurs only on newly expanding leaves, it is commonly called "frizzletop" (Dickey, 1977). These frizzled leaves are usually much shorter in length than normal leaves. The presence of $\mathrm{Mn}$ deficiency symptoms in midcanopy or lower leaves is indicative of a chronic Mn deficiency, whereas a few tiny and severely frizzled leaves at the top of the canopy followed by normal-sized and colored mid- to lower canopy leaves is characteristic of an acute Mn deficiency. The latter is often fatal in palms. Chronic Mn-deficient palms are superficially similar in appearance to those with late-stage $\mathrm{K}$ deficiency, with both displaying small, chlorotic, and necrotic-tipped leaflets. However, on Mn-deficient leaves, symptoms are most severe at the base of the leaf, whereas the reverse pattern characterizes K-deficient leaves (Broschat, 2005a). Mn deficiency is usually caused by high soil $\mathrm{pH}$, although transient, cold temperature-induced Mn deficiency is fairly common in coconut palm in Florida (Broschat and Donselman, 1985). The use of composted sewage sludges as soil amendments or fertilizers has also been shown to cause severe and long lasting Mn deficiencies in palms (Broschat, 199la).

Boron. Boron deficiency is widespread among landscape and fieldgrown palms throughout the world (Hartley, 1988; Manciot et al., 1980), but is rather rare in container-grown palms. Symptoms are extremely diverse, even within a single palm species. Very mild B deficiency can cause hair-like transverse or parallel translucent streaking on the leaflets of the newest leaves, transverse puckering, corrugations, or crumpling of the leaflets, the latter sometimes called "accordionleaf" (Broschat, 2005b; Dufour and Quencez, 1979; Kamalakshiamma and Shanavas, 2002; Marlatt, 1978). Leaflet tips may also be sharply hooked in a zigzag fashion, with this symptom being called "hookleaf" (Brunin and Coomans, 1973; Corrado et al., 1992). Mild B deficiency can also cause inflorescence necrosis and premature fruit drop (Broschat, 2007a; Kamalakshiamma and Shanavas, 2002). One of the most common symptoms of B deficiency is the failure of spear leaves to open normally, the leaflets being tightly fused along some or all of their length (Broschat, 2007a; Brunin and Coomans, 1973; Manciot 
et al., 1980). Healthy palms of most species will never have more than one unopened spear leaf at any given time. The presence of more than one unopened spear leaf is indicative of B deficiency. Boron-deficient leaves are unusually brittle, giving rise to the name "brittleleaf." As B deficiency becomes more severe, only tiny new leaves emerge ("little leaf" symptom), typically with shortened or no leaflets (Corrado et al., 1992; Manciot et al., 1980; Rajaratnam, 1972). The palm may die.

Boron deficiency can be transient to chronic, and mild to lethal in palms. A common symptom caused by a temporary insufficiency of $\mathrm{B}$ in the soil is a necrosis at a point on the axis of a primordial spear leaf. When this affected leaf emerges several months later and expands, the point necrosis will be manifested as an angular truncation of the leaflets where they were intersected by this necrosis (Corrado et al., 1992; Kamalakshiamma and Shanavas, 2002). If this temporary deficiency is severe enough, the entire tip of the leaf beyond the necrotic point will often fall off. This very temporary deficiency is believed to be caused by a single heavy leaching event lasting as little as $\mathrm{l} \mathrm{d}$. In rainy climates, this pattern may be repeated every time a heavy leaching rainfall occurs and as many as three such events have been documented during the development of a single leaf of a coconut palm (Broschat, 2007a).

On the other hand, B deficiency is known to be caused by soil drying and rewetting, which tightly binds soluble B (Biggar and Fireman, 1960; Keren and Gast, 1981). Soil drying and high soil $\mathrm{pH}$ (Goldberg, 1997) are believed to be the primary causes of chronic B deficiencies in palms. One of the most unusual symptoms of chronic B deficiency in palms is epinastic growth. When this occurs, the shoot axis of the palm may bend sharply in one direction or may even grow downward (Broschat, 2007a, 2007b). Twisting of individual leaves or even the entire shoot is not unusual. Epinastic growth in Bdeficient palms is believed to be due to excessive accumulations of auxin (indoleacetic acid) in B-deficient palms (Rajaratnam, 1972). Although $\mathrm{B}$ deficiency can kill the meristem in palms, it also is known to cause branching in species that normally do not branch (Broschat, 2007b).

While B toxicity has not been documented in landscape, or container- or field-grown palms, it has been induced experimentally in parlor palm (Chamaedorea elegans) and areca palm (Dypsislutescens) (Broschat, 2005d; Marlatt, 1978). Symptoms of B toxicity appear on all but the youngest leaves as leaflet tip necrosis. Becasuse these symptoms are similar to those caused by high soil soluble salts, water stress, or other chemical toxicities, correct diagnosis may require leaf nutrient analysis. Excessive accumulations of other nutrient elements generally do not result in toxicity symptoms, but rather as salt injury or induced deficiency symptoms of other antagonistic elements such as $\mathrm{Fe}$.

OTHER NUTRIENT DEFICIENCIES. Although deficiencies of sulfur (S), zinc $(\mathrm{Zn})$, copper $(\mathrm{Cu})$, chloride $(\mathrm{Cl})$, and molybdenum (Mo) have been induced experimentally in several species of palms using sand culture methods (Broeshart et al., 1957; Broschat, 1984; Bull, 1961a; Marlatt and McRitchie, 1979), deficiencies of these elements are rarely encountered in the landscape or in field nursery. Sulfur deficiency causes chlorosis of the youngest leaves, with leaf size and leaflet tip necrosis increasing with increasing severity (Broeshart et al., 1957; Broschat, 1984; Manciot et al., 1980). It has been reported on coconut palm in New Guinea and Madagascar, and on african oil palm in Ivory Coast (Cavez et al., 1976; Ollagnier and Ochs, 1972; Southern, 1969).

Copper deficiency causes stunted new leaves to be produced, with leaflets reduced in size and with extensive tip necrosis. Eventually, only necrotic petiole stubs emerge and death of the meristem often follows (Broschat, 1984; von Uexkull and Fairhurst, 1991). Copper deficiency has been reported on african oil palm grown in Sumatra (Ng and Tan, 1974).

Broschat (1984) found that experimentally induced chloride (Cl)-deficient clustering fishtail palm (Caryota mitis) and pygmy date palm (Phoenix roebelenii) had chlorotic new leaves, with leaflets in the latter species remaining partially fused around their margins, giving them a ladderlike appearance. Although visible symptoms of this deficiency have never been reported in palm production, fruit yields for coconut and african oil palm have been significantly improved with $\mathrm{Cl}$ fertilization in the Philippines (Magat et al., 1988; Ollagnier and Ochs, 1971).

Diagnosis OF NUTRITIONAL DISORDERs. While leaf and soil analysis have long been used as tools for diagnosing nutrient deficiencies or toxicities in common agronomic and horticultural crops, databases of plant response data versus leaf or soil nutrient concentrations are lacking for most palm species. von Uexkull and Fairhurst (1991) provide critical foliar elemental concentrations for african oil palm and Elliott et al. (2004) give similar values for areca palm, bamboo palm (Chamaedorea seifrizii), parlor palm, kentia palm (Howea forsterana), lady palm (Rhapis excelsa), and pygmy date palm. Leaf, and especially soil, nutrient concentrations often do not correlate well with visual symptoms expressed by palms. For example, foliar Fe concentrations are often poorly correlated with chlorosis severity in many species of plants (Jones et al., 1991). Also, foliar B concentrations in the youngest fully expanded leaves reflect the $\mathrm{B}$ status of the palm about 4 months before the sampling date and not the current B status (Broschat, manuscript in preparation). The presence of sufficient plant-available nutrients in the soil is no guarantee that such nutrients will actually be taken up by the palm in adequate amounts. Thus, the primary means of diagnosing palm nutritional disorders is by visual symptoms. Elliott et al. (2004) and Broschat (2005a) provide color photos of all the palm nutrient deficiencies discussed in this article. A key to nutritional disorders, as well as diseases and other physiological disorders with which they may be confused, has been developed by Broschat and Elliott (2005b).

\section{Palm fertilization}

Because correction of existing nutrient deficiencies in palms can take up to 2 years or longer, and symptomatic leaves will be present on the palm during that time, emphasis should be placed on fertilization to prevent deficiencies rather than treatment of existing deficiencies in palms. Also, because prolonged treatment 
with single-element fertilizers has been shown to upset critical elemental ratios (e.g., $\mathrm{N}: \mathrm{K}, \mathrm{N}: \mathrm{Mg}$, and $\mathrm{K}: \mathrm{Mg}$ ) in the soil and therefore induce or exacerbate deficiencies of other antagonistic elements, complete fertilizers should be used for routine production and maintenance fertilization (Broschat, 2005b). Although most palms in container production and in the landscape are fertilized with soil-applied granular fertilizers, foliar fertilization has been successfully used for rapid, but shortterm, correction of $\mathrm{N}, \mathrm{Fe}$, and $\mathrm{Mn}$ deficiencies, but not for $\mathrm{K}$ and $\mathrm{Mg}$ deficiencies. Foliar applications are most successful in cases where soil conditions (e.g., high $\mathrm{pH}$ ) limit the effectiveness of soil-applied micronutrients, or where compromised root systems are incapable of absorbing soil-applied nutrients.

Fertilization of palms in CONTAIners. Palms growing in containers present no special problems for fertilization. Fertilization regimes used for other woody ornamental crops have usually been effective in producing deficiency symptom-free palms (Conover et al., 1975; Broschat, 2005 e). Because many container substrates contain organic components such as pine bark that are known to tie up N (Ogden et al., 1987), high N fertilization rates are required. Conover et al. (1975) recommend application rates of $216 \mathrm{lb} /$ acre $\mathrm{N}$ per year for parlor palms grown under $73 \%$ shade and $270 \mathrm{lb} /$ acre $\mathrm{N}$ per year for areca palm and bamboo palm grown under $55 \%$ shade. When fertigation was used, Poole and Henley (1981) found that rates greater than 250 ppm $\mathrm{N}$ decreased growth of parlor palm. Palms growing under full sun conditions will require higher fertilization rates. Resin-coated controlledrelease fertilizers with longevities of 6 months or longer and a ratio of $3 \mathrm{~N}-0.4 \mathrm{P}-1.7 \mathrm{~K}$ are recommended because palms will typically remain in a given container size for at least 6 months (Broschat, 2005e). Similar high $\mathrm{N}$ fertilizers are recommended for container-grown palms at the time of transplanting into the landscape for the first 6 months while the bulk of the root system is still confined to this substrate. Substrates to be used for container palm production should have a complete micronutrient blend incorporated at the time of mixing because Broschat and Moore (2007) have shown that micronutrients contained within resin-coated prills generally do not release as effectively as $\mathrm{N}$ or other macronutrients. These substrates should also incorporate up to $15 \mathrm{lb} /$ yard $^{3}$ of dolomitic limestone, not for $\mathrm{pH}$ regulation, but as a slowrelease source of $\mathrm{Mg}$, an element typically lacking or insufficient in most container fertilizers.

FERTILIZATION OF FIELD NURSERY OR LANDSCAPE PALMS. Because field and landscape soils are very different in chemical and physical properties from those used in container production, recommended fertilizer formulations are very different for these two growing environments. Fertilization of field nursery or landscape palms depends on the soil type and climate in which they will be grown. To date, research on this subject has been done only for Florida on sandy and limestone soils where deficiencies of $\mathrm{N}$, $\mathrm{K}, \mathrm{Mg}, \mathrm{Fe}, \mathrm{Mn}$, and $\mathrm{B}$ are endemic. Broschat (2001) found that a fertilizer with an analysis of $8 \mathrm{~N}-0.9 \mathrm{P}-$ $10 \mathrm{~K}-4 \mathrm{Mg}$ plus $2 \% \mathrm{Mn}$ and $\mathrm{Fe}$ and trace amounts of $\mathrm{Zn}, \mathrm{Cu}$, and $\mathrm{B}$ was capable of producing deficiency symptom-free palms. However, due to the low cation exchange capacity of these soils and high rainfall and leaching potential, only products having $100 \%$ of their $\mathrm{N}, \mathrm{K}$, and $\mathrm{Mg}$ in controlled-release form were successful in eliminating all deficiency symptoms from palms. Micronutrients such as $\mathrm{Fe}, \mathrm{Mn}, \mathrm{Zn}$, and $\mathrm{Cu}$ should be in water-soluble form to be effective on neutral to alkaline $\mathrm{pH}$ soils (Broschat, 1991b; Mortvedt et al., 1972 ). This $8 \mathrm{~N}-0.9 \mathrm{P}-10 \mathrm{~K}-4 \mathrm{Mg}$ formulation is applied every 3 months at a rate of $15 \mathrm{lb} / 1000 \mathrm{ft}^{2}$ of palm canopy or landscape area for landscape palm maintenance (Broschat, $2005 \mathrm{~b})$. The same product is used in field nurseries at about twice the landscape maintenance rate. Similar products that contain no $\mathrm{N}$ may be preferable for palms grown on muck soils because the $\mathrm{N}$ released from the breakdown of these soils combined with that in the $8 \mathrm{~N}-0.9 \mathrm{P}-10 \mathrm{~K}-4 \mathrm{Mg}$ product used for sandy soils appears to exceed the optimum $\mathrm{N}: \mathrm{K}$ and $\mathrm{N}: \mathrm{Mg}$ ratios required for palms and thus exacerbates $\mathrm{K}$ and $\mathrm{Mg}$ deficiencies on these soils. When a $16 \mathrm{~N}-$ 1.7P-6.7K turf fertilizer was applied to areca palms in a sandy Florida soil,
K deficiency severity was equal to that of unfertilized control palms and $\mathrm{Mg}$ deficiency severity was worse than in unfertilized control palms (Broschat et al., 2008). Additional research is needed in Florida to determine optimum $\mathrm{N}: \mathrm{K}$ and $\mathrm{N}: \mathrm{Mg}$ ratios for calcareous fill and muck soils and optimum application rates for field production and landscape maintenance on all soils. Although fertilizer recommendations developed for Florida may, with minor adjustments, be suitable for palms grown in other states within the Atlantic coastal plain, original research on landscape palm fertilization needs to be done for other southern and western states that grow palms in very different soils and climates.

\section{Literature cited}

Biggar, J.W. and M. Fireman. 1960. Boron adsorption and release by soils. Soil Sci. Soc. Amer. Proc. 24:115-120.

Broeshart, H., J.D. Ferwerda, and W.G. Kovachich. 1957. Mineral deficiency symptoms of the oil palm. Plant Soil 8:289-300.

Broschat, T.K. 1984. Nutrient deficiency symptoms in five species of palms grown as foliage plants. Principes 28:6-14.

Broschat, T.K. 1990. Potassium deficiency of palms in south Florida. Principes 34:151-155.

Broschat, T.K. 1991a. Manganese binding by municipal waste composts used as potting media. J. Environ. Hort. 9:97100 .

Broschat, T.K. 1991b. Effects of manganese source on manganese uptake by pygmy date palms. HortScience 26:13891391.

Broschat, T.K. 1994. Removing potassium-deficient leaves accelerates rate of decline in pygmy date palms. HortScience 29:823.

Broschat, T.K. 1997. Nutrient distribution, dynamics, and sampling in coconut and canary Island date palms. J. Amer. Soc. Hort. Sci. 122:884-890.

Broschat, T.K. 2001. Development of an effective fertilization program for palms and other tropical ornamental plants in south Florida landscapes. Univ. Florida, Ft. Lauderdale Res. Educ. Ctr. Res. Rpt. 01-01.

Broschat, T.K. 2005a. Nutrient deficiencies of landscape and field-grown palms in Florida. Univ. Florida, Environ. Hort. 
Dept. Circ. ENHI018, 13 Feb. 2009. <http://edis.ifas.ufl.edu/EP273>.

Broschat, T.K. 2005b. Fertilization of field-grown and landscape palms in Florida. Univ. Florida, Environ. Hort. Dept. Circ. ENH1009, 13 Feb. 2009. <http:// edis.ifas.ufl.edu/EP261>.

Broschat, T.K. 2005c. Magnesium deficiency in palms. Univ. Florida, Environ. Hort. Dept. Circ. ENH1014, 13 Feb. 2009. <http://edis.ifas.ufl.edu/EP266>.

Broschat, T.K. 2005d. Physiological disorders of palms. Univ. Florida, Environ. Hort. Dept. Circ. ENH1011, 13 Feb. 2009. <http://edis.ifas.ufl.edu/EP263>.

Broschat, T.K. 2005e. Nutrition and fertilization of palms in containers. Univ. Florida, Environ. Hort. Dept. Circ. ENH1010, 13 Feb. 2009. <http://edis. ifas.ufl.edu/EP262>.

Broschat, T.K. 2007a. Boron deficiency symptoms in palms. Palms 51:115-126.

Broschat, T.K. 2007b. Boron deficiency, phenoxy herbicides, stem bending, and branching in palms: Is there a connection? Palms 51:161-163.

Broschat, T.K. and H. Donselman. 1985. Causes of palm nutritional disorders. Proc. Florida State Hort. Soc. 98:101102.

Broschat, T.K. and K.A. Moore. 2007. Release rates of ammonium-nitrogen, nitrate-nitrogen, phosphorus, potassium, magnesium, iron, and manganese from seven controlled release fertilizers. Commun. Soil Sci. Plant Anal. 38:843-850.

Broschat, T.K. and M.L. Elliott. 2005a. Effects of iron source on iron chlorosis and Exserohilum leaf spot severity in Wodyetia bifurcata. HortScience 40: 218-220.

Broschat, T.K. and M.L. Elliott. 2005b. A key to common landscape palm disorders and diseases in the continental United States. Palms 49:143-148.

Broschat, T.K., D.R. Sandrock, M.L. Elliott, and E.F. Gilman. 2008. Effects of fertilizer type on quality and nutrient content of established landscape plants in Florida. HortTechnology 18:278-285.

Brunin, C. and P. Coomans. 1973. La carence en bore sur jeunes cocotiers en Côte D'Ivoire. Oléagineux 28:229-234.
Bull, R.A. 1958. Symptoms of calcium and phosphorus deficiency in oil palm seedlings. Nature 182:1749-1750.

Bull, R.A. 1961a. Studies on the deficiency diseases of the oil palm. 2. Macronutrient deficiency symptoms in oil palm seedlings grown in sand culture. J. West African Inst. Oil Palm Res. 3:254-264.

Bull, R.A. 1961b. Studies on the deficiency diseases of the oil palm. 3. Micronutrient deficiency symptoms in oil palm seedlings grown in sand culture. J. West African Inst. Oil Palm Res. 3:265-272.

Cavez, C., J. Olevin, and J.L. Renard. 1976. Etude d'une déficience en soufre sur jeunes palmier à huile en Côte D'Ivoire. Oléagineux 31:251-257.

Conover, C.A., R.T. Poole, and R.W. Henley. 1975. Growing acclimatized foliage plants. Florida Foliage Grower 12(9):1-4.

Corrado, F., P. Quencez, and B. Taillez. 1992. La déficience en bore chez le palmier à huile. Symptômes et corrections. Oléagineux 47:719-725.

Dickey, R.D. 1977. Nutritional deficiencies of woody ornamental plants used in Florida landscapes. Univ. Florida, Agr. Expt. Sta. Bul. 791.

Dufour, F. and P. Quencez. 1979. Étude de la nutrition en oligo-éléments du palmier à huile et du cocotier cultivés sur solutions nutritives. Oléagineux 34:323328.

Elliott, M.L., T.K. Broschat, J.Y. Uchida, and G.W. Simone. 2004. Compendium of ornamental palm diseases and disorders. APS Press, St. Paul, MN.

Goldberg, S. 1997. Reactions of boron with soils. Plant Soil 193:35-48.

Hartley, C.W.S. 1988. The oil palm. Longman Scientific and Technical, Essex, UK.

Jones, J.B., Jr., B. Wolf, and H.A. Mills. 1991. Plant analysis handbook. MicroMacro Publishing, Athens, GA.

Kamalakshiamma, P.G. and M. Shanavas. 2002. Boron deficiency in coconut: Symptoms and correction. Indian Coconut J. 32(11):1-5.

Keren, R. and R.G. Gast. 1981. Effects of wetting and drying, and of exchangeable cations on boron adsorption and release by montmorillonite. Soil Sci. Soc. Amer. J. 45:478-482.
Magat, S.S., R.Z. Margate, and J.A. Habana. 1988. Effects of increasing rates of sodium chloride (common salt) fertilization on coconut palms grown under an inland soil (Tropudalfs) of Mindanao, Philippines. Oléagineux 43:13-19.

Manciot, E., M. Ollagnier, and R. Ochs. 1979. Mineral nutrition of the coconut around the world. Oléagineux 34:511515, 576-580.

Manciot, E., M. Ollagnier, and R. Ochs. 1980. Mineral nutrition of the coconut around the world. Oléagineux 35:23-27.

Marlatt, R.B. 1978. Boron deficiency and toxicity symptoms in Ficus elastica 'Decora' and Chrysalidocarpus lutescens. HortScience 13:442-443.

Marlatt, R.B. and J.J. McRitchie. 1979. Zinc deficiency symptoms of Chrysalidocarpus lutescens. HortScience 14:620621.

Mortvedt, J.J., P.M. Giordano, and W.L. Lindsay (eds.). 1972. Micronutrients in agriculture. Soil Sci. Soc. Amer., Madison, WI.

Ng, S.K. and Y.P. Tan. 1974. Nutritional complexes of oil palms planted on peat in Malaysia. I. Foliar symptoms, nutrient composition, and yield. Oléagineux 29: $1-8$.

Ogden, R.J., F.A. Pokorny, H.A. Mills, and M.G. Dunavent. 1987. Elemental status of pine bark-based potting media. Hort. Rev. (Amer. Soc. Hort. Sci.) 9:103131.

Ollagnier, M. and R. Ochs. 1971. Le chlore, nouvel élément essential dans la nutrition du palmier à huile et la nutrition en chlore du palmier à huile et du cocotier. Oléagineux 26:1-15, 367-372.

Ollagnier, M. and R. Ochs. 1972. Sulphur deficiencies in the oil palm and coconut. Oléagineux 27:193-198.

Poole, R.T. and R.W. Henley. 1981. Constant fertilization of foliage plants. J. Amer. Soc. Hort. Sci. 106:61-63.

Rajaratnam, J.A. 1972. Observations on boron-deficient oil palms (Elaeis guineensis). Exp. Agr. 8:339-346.

Southern, P.J. 1969. Sulphur deficiency in coconuts. Oléagineux 24:211-220.

von Uexkull, H.R. and T.H. Fairhurst. 1991. Fertilizing for high yield and quality the oil palm. Intl. Potash Inst., Berne, Switzerland. 